Titel: Die Sideboard

Outeur: Simon Bruinders

Uitgewer: Naledi

Bladsye: 261

Prys: R179

\title{
Die Sideboard - 'n altaar en 'n teken van 'n regverdige God
}

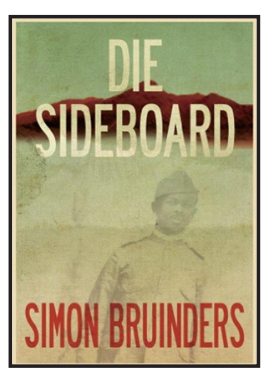

In sy debuutroman vertel Bruinders van die pyn wat bruinmense in die Suid-Kaap moes deurmaak toe hulle grond en huise afgevat is. Die Sideboard is die verhaal van Abraham de Bruin (die naam en van kom met sy eie metafore) en sy gesin wat oor 'n tydperk van 30 jaar talle terugslae in die lewe moes hanteer. In die proses verloor hy nie net die huis wat hy self gebou het nie, maar ook die kosbare sideboard, 'n geskenk wat hy met sy eie hande vir sy vrou (Stella) gemaak het vir hul derde huweliksherdenking. Dis 'n verhaal van mense wat onwrikbaar glo in God se Hoër Hand; dat Hy hulle lewens rig. Dis ook 'n verhaal waar mense begin twyfel in God as hulle geloof tot die uiterste beproef word.

Maar laat ek heel voor begin.

Die verhaal begin in Oktober 1939 waar Abraham, die hoofkarakter, hoog teen die Outeniquaberge teeblare pluk. Dis vrek warm en boonop 'n uiters gevaarlike werk, maar die paar oulap wat hy hiervoor verdien, vul sy salaris as meubelmaker op George mooi aan en stel hom in staat om gereeld 'n geldjie weg te sit. Hy spaar doelgerig, want hy is reeds 30 jaar oud en alhoewel steeds ongetroud, wil hy eendag sy eie stukkie besit waar hy 'n huis vir hom en Stella (die onderwyseres wat hy hartstogtelik bemin) en hul kinders wil bou (7). Stella herinner voortdurend die leerders in haar klas dat Outeniqua beteken "die man met heuning".

Abraham woon saam met sy ma, Miena, en sy broer Stanley op 'n plot net langsaan die Venters. Miena het as vroedvrou menige kind, wit en bruin, die lewe ingehelp. Sy is juis op daardie oomblik besig om Anna en Groot KoosVenter se eerste kleinseun die lewe in te help. Groot Koos is opgewonde oor sy skoondogter, Lenie en hul seun Gert, se eerste kind 'n seun is, want hulle moet die Afrikanervolk bou (9).

Bruinders slaag daarin om van meet af dié twee sentrale temas by die leser tuis te bring: Abraham de Bruin, simbolies die stamvader van die bruinmense se ambisie en versugting om sy eie grond te besit in 'n tyd toe die uitbreiding van eie grondgebied juis vir die Afrikaners 'n prioriteit was. In Abraham se soeke na identiteit en erkenning speel Stella as vroulike hoofkarakter, 'n sentrale rol. Sy ontsien geen moeite om hom te leer skrywe en lees nie (49). Wanneer hy die dag met Stella trou, kan hy nie net sy eie naam skryf nie, hy onderteken sy trousertifikaat (56) en bevestig so sy nuut gevonde identiteit.

Toe Abraham dus kort na sy troue met Stella (56) net 'n week voor Krismis (55) aankondig dat hy saam met die Engelse teen die Duitsers in die tweede Wêreldoorlog gaan baklei (61) was dit te verstane, juis omdat Jan Smuts beloof het dat almal wat oorlog toe gaan, sal grond kry. Abraham het dus ambisie gehad om op sy eie grond te boer omdat hy "so 'n groen hand gehad het" (63). Maar vir Groot Koos Venter was dit verregaande dat "grond aan die Hotnots gegee sou word" (62).

Die spanning verdiep toe die rekrute na die oorlog vertrek. "Tien stuks jong Afrikaners " het die rekrute asook vir Kobus wat, soos altyd, langs Abraham ingeval het, uitgejou (79). Kobus se 
broer, Gert, is die voorbok en snou sy broer woorde toe soos "Hotnotboetie", 'n woord wat hy kennelik by sy pa, Groot Koos, geleer het.

Dit was nie lank nie of Stella was swanger met die eerste van haar vyf kinders (85). Getrou aan die tradisie van sy Bybelse naamgenoot het Abraham nie op hom laat wag nie! Intussen het die geallieerde magte hul aanslag op die Duitsers verskerp. Terwyl Stella en Ma Miena die boerdery aan die gang gehou het (94), is Abraham en Kobus na Abessinië in die noorde van Afrika (91). Dis hier in Addis Abeba waar Abraham die mooiste sideboard nog sien, en hy besluit dat hy eendag vir Stella so een gaan maak.

Die Kaapse Korps is sedert 1942 vir die eerste keer met wapens toegerus en by werklike gevegte betrek. Die oorlog was opwindend, maar lewensgevaarlik (105). Dit was onvermydelik dat iemand sou seerkry: Kobus word gewond, maar oorleef danksy Abraham wat sy lewe waag om hom te red (113). Abraham is minder gelukkig. Hy is swaar gewond en moes terugkeer huis toe (114). Presies hoe dit gebeur, moet die leser self verder lees.

$\mathrm{Na}$ 'n paar maande begin hy weer by die saagmeule werk, en dis nie lank nie of hy besluit om die sideboard vir Stella te maak “...- met hout uit sy eie wêreld: swart-en geelhout. Stella verwag reeds hul derde kind en die sideboard moes klaar voor die baba kom (121). Op 17 Desember 1943 het die sideboard sy intrek in die De Bruins se voorkamer geneem. Teen 6 voet 2 duim het dit die helfte van die groot voorkamer volgestaan.

Maar dit was nie net 'n sideboard nie: “Dit moe(s) 'n altaar wees. 'n Teken van die regverdige God wat my uit die oorlog teruggebring het huis toe" (123). Elke aand het Stella Die Bybel van die sideboard gehaal en vir hulle voorgelees. Abraham se geliefde stuk was die deel oor God se belofte aan Abraham, die belofte oor kinders en die beloofde grond. Die sideboard sou altyd 'n ereplek in die huis hê" (123). Teen die tyd dat D-dag op 6 Junie 1944 aanbreek, was Abraham reeds die trotse pa van vier kinders. Die vyfde kind was 'n dogter.

Die sideboard en die De Bruin-gesin sou egter vele aanslae moes trotseer. Toe 'n brand een nag die gesin se huis in puin gelê het, kon hulle genadiglik die sideboard red uit die vlamme (141). Die hardwerkende Abraham weet egter nie van moed opgee nie. Hy bou vir hom 'n nuwe huis van bakstene op dieselfde plek. Net mooier en groter (144).

Die lewe het voortgegaan. By die skool is Kobus se kinders die rassistiese woorde van "hotnots" en "kaffers" geleer en al het hy en Abraham die kinders getug, is die eerste saadjie van rassisme toe al geplant. 'n Onheilspellende aanduiding van wat sou kom. In 1964 is die ANC se Rivonia-leiers Robbeneiland toe gestuur, Die Afrikaner was stewig in beheer en Afrikanernasionalisme het begin blom (184). Die groepgebiedewet nr. 41 van 1950 het ook vir George en sy mense getref. Eers moes Miena die huis waarheen sy 25 jaar gelede getrek het, ontruim. Die Bosbou het glo die grond verkoop. Bejaarde weduwees van oor die 80 moes hulle huise wat op kerkgrond gestaan het, verlaat (189). Ook Abraham en sy gesin moes trek. Uit die huis wat hy self gebou het, na die afbrand van sy eerste huis, na 'n onbekende stuk grond. Die Eiland is wit verklaar (200).

Weer murmureer Abraham teen God: "Is God dan net 'n God vir witmense?" vra hy verbitterd. Waarom altyd hulle wette. Lees ons dieselfde Bybel? (201). Die pyn het nie hier geëindig nie. Die sideboard kon nie saam trek na die lokasie nie, want daai huisies was te klein (212). Hulle moes die sideboard verkoop. Vir Abraham was dit die laaste strooi. Hy stort ineen en beland in 'n inrigting (228) waar hy 'n tydperk vertoef voordat hy sterk genoeg is om terug te keer na sy "nuwe" huisie.

'n Maand later is die grond waarop die Sendingkerk (van die bruinmense) gebou is, met kerk en al aan ontwikkelaars verkoop sodat die eerste supermark, Checkers, daar gebou kon word. Die Kerk "is tot op die grond afgebreek" (250). Die NP-regering het al hoe meer arrogant geword. 
Nie net is mense uit hul huise verjaag nie, sommige huise, soos die van Abraham se broer en die Tamboers, is platgestoot.

Bruinders stel ook die leser bekend aan 'n paar taaljuwele so reg uit die mond van die SuidKaapse bruinman: Abraham het sy geld weggesit (spaar), en net voor Krismis getrou (55). Van die inwoners het dikwels vir Kaaitje Langnek gesoen (gedrink, 63). 'n Boerjong of plaasjapie (109) is boejong gedoop; vaders moes papgelt (105) betaal (onderhoud vir die ma) en het nie geskroom om hulle se tjinners (123) op te neuk nie (169).

Ten spyte van al die hartseer en pyn kan die leser uitsien na 'n gelukkige einde. Kobus en sy vrou sou 30 jaar later Abraham en Stella se Sideboard by 'n vendusie opspoor. Hulle koop dit en gee die sideboard as geskenk terug aan Abraham en Stella op hul $30^{\text {ste }}$ huweliksherdenking. Niemand was blyer as Abraham nie. "My vrou is da'm gelukkig. Twee keer in haar lewe kry sy op haar huweliksherdenking dieselfde present" (262).

Vir hierdie skrywer wat hierdie roman met 'n universiteitsklas - met al sy diverse kulture van die moderne samelewing moes behandel, is die grootste wins die feit dat Bruinders se boek 'n gebalanseerde weergawe van die geskiedenis vertel. Abraham se vriendskap met sy buurman, Kobus, iemand saam met wie hy groot geword het, bewys dat nie alle witmense ongevoelig gestaan het teenoor die pyn van hul bruin familie nie.Daarvoor gee ek vir Bruinders 10 uit 10! Einde.

\section{Michael le Cordeur}

Hoof van die Departement Kurrikulumstudies

Universiteit Stelenbosch

E-pos: mlecorde@sun.ac.za 
